\title{
Pengaruh Bahan Ajar Video Tutorial Terhadap Hasil Belajar Pada Pembelajaran Online di Masa Pandemi Covid-19
}

\author{
Ida Bagus Ardhi Putra
}

Institut Teknologi dan Kesehatan Bali, ib.ardhiputra@gmail.com

I Putu Gede Sutrisna

Institut Teknologi dan Kesehatan Bali, putusutrisna92@gmail.com

\begin{abstract}
Abstrak
Penelitian ini bertujuan untuk mengetahui (1) perbedaan hasil belajar mahasiswa dalam mata kuliah Pengenalan Teknologi Informasi antara kelas yang menggunakan bahan ajar video tutorial dan kelas yang menggunakan bahan ajar modul, (2) peningkatan hasil belajar mahasiswa akibat penggunaan bahan ajar video tutorial. Penelitian kuasi eksperimen ini menggunakan dua kelompok, yaitu kelompok eksperimen yang menggunakan bahan ajar video tutorial dan kelompok kontrol yang menggunakan bahan ajar modul. Kedua kelas berlangsung secara online menggunakan Google Classroom. Populasi penelitian adalah mahasiswa Semester II Program Studi D-IV Keperawatan Anestesiologi di ITEKES Bali yang menempuh mata kuliah Pengenalan Teknologi Informasi. Sampel penelitian berjumlah 80 mahasiswa terbagi atas 40 mahasiswa kelompok kontrol dan 40 mahasiswa kelompok eksperimen. Pengumpulan data menggunakan instrumen tes soal pilihan ganda. Hasil penelitian menunjukkan (1) ada perbedaan yang signifikan antara hasil belajar mahasiswa yang menggunakan bahan ajar video tutorial dan mahasiswa yang menggunakan bahan ajar modul, (2) ada peningkatan hasil belajar mahasiswa yang signifikan akibat penggunaan bahan ajar video tutorial.
\end{abstract}

Kata Kunci: video tutorial, hasil belajar, pembelajaran online, pandemi covid-19.

\section{PENDAHULUAN}

Pandemi Covid-19 berdampak signifikan terhadap berbagai bidang kehidupan, salah satunya adalah kegiatan pembelajaran (Zhou dkk., 2020). Sejak virus Covid-19 menyebar di Indonesia, kegiatan belajar mengajar dilaksanakan dari rumah secara online. Pembelajaran di perguruan tinggi juga harus dilakukan dengan kegiatan yang mampu mencegah kontak secara fisik antara mahasiswa dengan mahasiswa maupun mahasiswa dengan dosen (Firman \& Rahayu, 2020). Kegiatan belajar mengajar yang semula secara tatap muka diganti secara mendadak dengan pembelajaran online mengakibatkan banyaknya pendidik dan peserta didik yang merasa tidak siap dengan hal tersebut.

Penggunaan teknologi informasi dalam pembelajaran membuat mahasiswa dan dosen dapat melaksanakan proses pembelajaran walaupun mereka di tempat yang berbeda. Bentuk perkuliahan yang dipilih sebagai solusi agar pembelajaran di dalam masa pandemi Covid-19 tetap berlangsung adalah pembelajaran online. Menurut Moore dkk. (2011), pembelajaran online adalah pembelajaran yang menggunakan jaringan internet dengan, konektivitas, aksesibilitas, fleksibilitas, dan kemampuan untuk memunculkan berbagai jenis interaksi pembelajaran. Pembelajaran online merupakan pembelajaran yang dapat mempertemukan dosen dan mahasiswa untuk melakukan kegiatan pembelajaran dengan bantuan jaringan internet (Kuntarto, 2017).

Pembelajaran online selama pandemi Covid-19 di Institut Teknologi dan Kesehatan (ITEKES) Bali khususnya pada mata kuliah Pengenalan Teknologi Informasi, terdapat beberapa kendala salah satunya adalah variasi bahan ajar. Berdasarkan hasil observasi pada saat perkuliahan secara online dan wawancara kepada beberapa dosen dan mahasiswa menunjukkan bahwa banyak mahasiswa yang 
mendapat kesulitan memahami bahan ajar pada saat pembelajaran online. Mahasiswa sulit memahami bahan ajar pada pembelajaran online yang kebanyakan berupa modul, slide presentasi, dan bahan bacaan karena hanya berupa teks dan gambar saja. Mahasiswa berpendapat bahwa membaca materi dan mengerjakan tugas saja tidak cukup. Mahasiswa menginginkan penjelasan langsung secara verbal dari dosen mengenai beberapa materi yang sifatnya kompleks. Komunikasi dan tanya jawab dengan dosen melalui aplikasi pesan ataupun pada kolom diskusi yang disediakan oleh aplikasi pembelajaran online tidak mampu memberikan penjelasan menyeluruh mengenai materi yang sedang dibahas.

Pemilihan jenis bahan ajar yang tepat dalam pembelajaran online merupakan hal penting untuk diperhatikan. Dengan adanya bahan ajar yang tepat maka peserta didik lebih mudah memahami materi pembelajaran, walaupun peserta didik belajar dari rumah. Pemilihan media pembelajaran yang tepat sebaiknya disesuaikan dengan karakteristik dan kemampuan peserta didik dalam menggunakan media pembelajaran (Ahmadi, 2017). Bahan ajar video dianggap tepat digunakan dalam pembelajaran online karena mudah digunakan oleh seluruh peserta didik (Susmiati, 2020; Alami, 2020). Dalam pembelajaran online di masa pandemi, pendidik tidak dapat mengajar melalui tatap muka secara langsung dengan peserta didik, maka bahan ajar video pembelajaran dianggap tepat untuk memudahkan pendidik menjelaskan materi pembelajaran (Atsani, 2020). Video pembelajaran juga dapat mengatasi kebosanan dan kejenuhan peserta didik saat belajar dari rumah (Hadi, 2017). Bahan ajar berupa video tutorial memberikan pengaruh yang positif pada pembelajaran. Beberapa hasil penelitian sebelumnya yang berkaitan dengan pengaruh video tutorial terhadap hasil belajar memberikan hasil peserta didik kelas eksperimen yang menggunakan video tutorial memiliki hasil belajar yang lebih lebih baik (Rudiawan, 2015).

Penelitian ini bertujuan untuk mengetahui (1) perbedaan hasil belajar mahasiswa antara kelas yang menggunakan pembelajaran online dengan bahan ajar video tutorial dengan kelas yang menggunakan pembelajaran online dengan bahan ajar modul, (2) peningkatan hasil belajar mahasiswa akibat penggunaan bahan ajar video tutorial. Adapun urgensi dalam penelitian ini adalah belum banyaknya penelitian tentang pengaruh bahan ajar video tutorial pada pembelajaran online di masa pandemi Covid-19 sehingga hasil penelitian ini dapat menjadi masukan dalam meningkatkan kualitas pembelajaran online.

\section{METODE}

Penelitian ini termasuk penelitian kuantitatif dengan pendekatan eksperimen semu (quasi experiment), yaitu penelitian eksperimen tetapi subjek penelitian tidak dipilih secara acak sepenuhnya (Sukardi, 2003). Subjek penelitian ini adalah kelas eksperimen dan kelas kontrol yang tidak dipilih secara acak. Tujuan penelitian ini adalah untuk mengetahui pengaruh penggunaan bahan ajar video tutorial pada pembelajaran online di mata kuliah Pengenalan Teknologi Informasi.

Penelitian diawali dengan menentukan kelompok eksperimen dan kelompok kontrol. Kelompok yang digunakan dalam penelitian ini berdasarkan kelas yang sudah terbentuk sebelumnya baik sebagai kelompok eksperimen maupun kelompok kontrol (Creswell, 2012). Desain yang digunakan adalah nonequivalent comparison-group design. Desain penelitian ditampilkan pada Tabel 1 di bawah ini:

Tabel 1. Nonequivalent Comparion-group Design

\begin{tabular}{|c|c|c|c|}
\hline Kelompok & Pretest & Treatment & Posttest \\
\hline Eksperimen & $\mathrm{O}_{1}$ & $\mathrm{X}_{1}$ & $\mathrm{O}_{2}$ \\
\hline Kontrol & $\mathrm{O}_{1}$ & $\mathrm{X}_{2}$ & $\mathrm{O}_{2}$ \\
\hline
\end{tabular}


Keterangan:

$\mathrm{O}_{1}$ : Pemberian instrumen tes tertulis (pretest)

$\mathrm{O}_{2}$ : Pemberian instrumen tes tertulis (posttest)

$\mathrm{X}_{1}$ : Perlakuan yang diberikan kepada kelas eksperimen berupa bahan ajar video tutorial pada pembelajaran online

$\mathrm{X}_{2}$ : Perlakuan yang diberikan kepada kelas kontrol berupa bahan ajar modul tertulis pada pembelajaran online

Populasi dalam penelitian ini adalah mahasiswa semester II Tahun Ajaran 2020/2021 Program Studi D-IV Keperawatan Anestesiologi ITEKES Bali yang menempuh mata kuliah Pengenalan Teknologi Informasi sebanyak 102 mahasiswa dan terbagi menjadi 2 kelas. Sampel yang digunakan dalam penelitian ini berjumlah 80 mahasiswa terbagi menjadi 2 kelas yaitu 1 kelas eksperimen dan 1 kelas kontrol. Penentuan kelas dilakukan secara random assignment, yaitu penentuan kelas dilaksanakan secara acak. Kedua kelas yang digunakan harus berasal dari populasi yang homogen. Hal ini dibuktikan dari hasil homogenitas pretest.

Variabel bebas untuk penelitian ini adalah bahan ajar yang terdiri dari bahan ajar video tutorial yang diterapkan pada kelas eksperimen dan bahan ajar modul yang diterapkan pada kelas kontrol. Variabel terikatnya adalah hasil belajar mata kuliah Pengenalan Teknologi Informasi. Skor hasil belajar adalah kemampuan yang dimiliki oleh mahasiswa secara akademik setelah melalui kegiatan belajar yang tercermin dari nilai tes pada mata kuliah Pengenalan Teknologi Informasi sesudah mengikuti kegiatan pembelajaran (posttest). Penelitian ini memiliki tahapan sebagai berikut:

1. Menyiapkan Bahan Ajar

Bahan ajar yang disiapkan berupa video tutorial untuk kelas eksperimen dan modul tutorial untuk kelas kontrol. Topik materi yang akan disiapkan bahan ajarnya pada matakuliah Pengenalan Teknologi Informasi adalah Analisis Data dengan SPSS sebanyak 4 pertemuan. Bahan ajar video tutorial dibuat dengan menggunakan software Camtasia Studio. Bahan ajar modul tutorial dibuat dengan Microsoft Word dan diubah menjadi file PDF. Video dan modul dibuat sebagai bahan ajar pada pembelajaran online pada kelas online dengan menggunakan Google Classroom.

2. Pembuatan Instrumen Penelitian

Pada tahap ini peneliti membuat kisi-kisi instrumen tes berupa pretest dan posttest lalu mengembangkan kisi-kisi menjadi instrumen penelitian. Langkah selanjutnya adalah melakukan validasi instrumen penelitian. Pada tahap ini dilakukan validasi expert judgement untuk instrumen tes tertulis.

3. Pelaksanaan Pretest

Tahap ini meliputi tes tertulis pada kelompok kontrol dan kelompok eksperimen untuk mengukur hasil belajar awal sebelum diberi perlakuan.

4. Pemberian Perlakuan

Kelompok kontrol dan eksperimen pada proses pembelajaran online menggunakan Google Classroom diberikan topik yang sama namun menggunakan bahan ajar yang berbeda. Kelompok eksperimen menggunakan bahan ajar video tutorial dan kelompok kontrol menggunakan bahan ajar modul tertulis. Pemberian perlakuan ini dilakukan untuk 4 kali perkuliahan secara online menggunakan Google Classroom.

5. Pelaksanaan Posttest

Tes dilakukan setelah proses pembelajaran online dengan perlakuan seperti dijelaskan pada poin (4) di atas. Tes yang diberikan meliputi tes tertulis untuk mengukur hasil belajar mahasiswa.

6. Analisis Data

Analisis data dan interpretasi hasil meliputi: skor tes tertulis (pretest) kelompok eksperimen, skor tes tertulis (pretest) kelompok kontrol, skor tes tertulis (posttest) kelompok eksperimen, dan skor tes tertulis 
(posttest) kelompok kontrol. Teknik analisis data menggunakan Independent sample ttest. Analisa data ini digunakan mengetahui apakah ada perbedaan rerata yang antara 2 kelompok yang berskala data rasio atau interval. Kelompok yang dimaksud di sini adalah dua kelompok yang tidak berpasangan, artinya sumber data berasal dari subjek yang berbeda. Sebelum uji ini dilakukan, maka harus dilakukan uji prasyarat (homogenitas dan normalitas).

\section{HASIL DAN PEMBAHASAN \\ Hasil}

\section{Data Pretes Kelompok Eksperimen Dan Kontrol}

Pretes dilakukan sebelum diberikan perlakuan atau sebelum pembelajaran dimulai. Tujuan dari pretes adalah untuk mengetahui pemahaman awal mahasiswa terhadap materi. Selain itu juga untuk mengetahui tingkat kesamaan kemampuan kelompok kontrol dan kelompok eksperimen.

Tabel 2. Ringkasan Hasil Deskriptif Pretes

\begin{tabular}{|l|l|l|l|l|l|}
\hline Kelompok & N & Mean & SD & Min & Max \\
\hline Eksperimen & 40 & 50,63 & 7,52 & 37 & 63 \\
\hline Kontrol & 40 & 52,30 & 7,34 & 37 & 63 \\
\hline
\end{tabular}

Berdasarkan Tabel 2 di atas, kelompok eksperimen diperoleh rata-rata (mean) $=50,63$; simpangan baku $=7,52$; skor terendah $=37$; skor tertinggi $=63$. Sementara kelompok kontrol diperoleh mean=52,30; simpangan baku $=7,34$; skor terendah $=37$; skor tertinggi $=63$; Berdasarkan data di atas, dapat dilihat bahwa rata-rata skor hasil belajar kelompok kontrol dan kelompok eksperimen tidak berbeda jauh, yaitu rata-rata skor kelompok eksperimen sebesar 50,63, sedangkan rata-rata skor kelompok kontrol sebesar 52,30. Hal ini menunjukan bahwa hasil pretest kedua kelompok tidak terdapat perbedaan yang signifikan.

Berdasarkan data hasil analisis uji homogenitas skor pretest kedua kelompok dengan uji lavene menunjukkan bahwa nilai sig. (p-value) pretest $>0,05$, dengan demikian kedua data homogen yang berarti kedua kelas memiliki rata-rata kemampuan awal yang sama sebelum diberikan perlakuan.

\section{Data Posttest Kelompok Eksperimen Dan Kontrol \\ Posttest dilakukan setelah diberikan} perlakuan dengan tujuan untuk mengetahui hasil belajar mahasiswa dengan bahan ajar yang berbeda pada pembelajaran online menggunakan Google Classroom. Kelompok eksperimen menggunakan bahan ajar berupa video tutorial sedangkan kelompok kontrol menggunakan bahan ajar modul tertulis. Perlakuan dilakukan selama 4 (empat) pertemuan secara online dengan topik Analisis Data dengan SPSS.

Tabel 3. Ringkasan Hasil Deskriptif Posttest

\begin{tabular}{|l|l|l|r|r|r|}
\hline Kelompok & N & Mean & SD & Min & Max \\
\hline Eksperimen & 40 & 74,43 & 13,75 & 50 & 97 \\
\hline Kontrol & 40 & 65,45 & 7,97 & 47 & 83 \\
\hline
\end{tabular}

Berdasarkan Tabel 3 di atas, kelompok eksperimen diperoleh rata-rata $($ mean $)=74,43$; simpangan baku $=13,75$; skor terendah $=50$; skor tertinggi $=97$. Sementara kelompok kontrol diperoleh mean $=65,45$; simpangan baku $=7,97$; skor terendah $=47$; skor tertinggi $=83$. Berdasarkan hasil data tersebut, dapat dilihat bahwa rata-rata hasil belajar kelompok eksperimen lebih tinggi dari kelompok kontrol.

\section{Uji Normalitas}

Uji normalitas dilakukan terhadap hasil belajar kelompok eksperimen dan kontrol menggunakan uji Shapiro-Wilk.

Tabel 4. Hasil Uji Normalitas Data

\begin{tabular}{|l|l|l|l|l|}
\hline & Bahan Ajar & N & Sig. & $\begin{array}{l}\text { Kesim } \\
\text { pulan }\end{array}$ \\
\hline $\begin{array}{l}\text { Pre } \\
\text { test }\end{array}$ & Video Tutorial & 40 & 0,086 & Normal \\
\hline & Modul & 40 & 0,057 & Normal \\
\hline $\begin{array}{l}\text { Post } \\
\text { test }\end{array}$ & Video tutorial & 40 & 0,061 & Normal \\
\hline & Modul & 40 & 0,314 & Normal \\
\hline
\end{tabular}


Berdasarkan hasil pengujian normalitas data pada Tabel 4 di atas, semua nilai signifikansi (p-value) $>0,05$. Hal ini menunjukkan bahwa semua kelompok data berdistribusi normal.

\section{Uji Homogenitas}

Uji homogenitas menggunakan Homogenity of Variance Test. Kriteria data homogen adalah jika nilai sig. lebih dari 0,05. Hasil perhitungan dengan SPSS ditampilkan pada Tabel 5.
Tabel 5. Hasil Uji Homogenitas

\begin{tabular}{|l|l|l|l|l|}
\hline & $\begin{array}{l}\text { Levene } \\
\text { Statistic }\end{array}$ & df1 & df2 & Sig. \\
\hline Skor Pretest &, 001 & 1 & 78 &, 979 \\
\hline Skor Posttest & 14,882 & 1 & 78 &, 000 \\
\hline
\end{tabular}

Berdasarkan hasil pada Tabel 5 di atas, dapat dilihat nilai signifikansi skor pretest adalah $0,979>0,05$ dan nilai signifikansi posttest adalah $0,001<0,05$. Hasil data ini menunjukkan bahwa data skor pretest homogen dan data skor posttest tidak homogen.

Tabel 6. Hasil Uji Independent Samples T-Test

\begin{tabular}{|c|c|c|c|c|c|c|c|c|c|c|}
\hline & \multicolumn{2}{|c|}{$\begin{array}{l}\text { Levene's Tes } \\
\text { for Equality of } \\
\text { Variances }\end{array}$} & \multicolumn{7}{|c|}{ t-test for Equality of Means } \\
\hline & & \multirow[t]{2}{*}{$\mathrm{F}$} & \multirow[t]{2}{*}{ Sig. } & \multirow[t]{2}{*}{$\mathrm{t}$} & \multirow[t]{2}{*}{$\mathrm{df}$} & \multirow[t]{2}{*}{$\begin{array}{l}\text { Sig. } \\
(2- \\
\text { tailed })\end{array}$} & \multirow[t]{2}{*}{\begin{tabular}{|l} 
Mean \\
Difference
\end{tabular}} & \multirow[t]{2}{*}{$\begin{array}{l}\text { Std. Error } \\
\text { Difference }\end{array}$} & \multicolumn{2}{|c|}{$\begin{array}{l}95 \% \text { Confidence } \\
\text { Interval of the } \\
\text { Difference }\end{array}$} \\
\hline & & & & & & & & & Lower & Upper \\
\hline \multirow{2}{*}{$\begin{array}{l}\text { Skor } \\
\text { Posttest }\end{array}$} & $\begin{array}{l}\text { Equal } \\
\text { variances } \\
\text { assumed }\end{array}$ & 14,882 & ,000 & 3,571 & 78 &, 001 & 8,975 & 2,514 & 3,971 & 13,979 \\
\hline & \begin{tabular}{|l} 
Equal \\
variances \\
not \\
assumed
\end{tabular} & & & 3,571 & 62,542 &, 001 & 8,975 & 2,514 & 3,951 & 13,999 \\
\hline
\end{tabular}

Tabel 7. Hasil Uji paired Samples T-Test Hasil Belajar

\begin{tabular}{|c|c|c|c|c|c|c|c|}
\hline \multicolumn{5}{|c|}{ Paired Differences } & \multirow[t]{3}{*}{$\mathrm{t}$} & \multirow[t]{3}{*}{$\mathrm{df}$} & \multirow{3}{*}{$\begin{array}{l}\text { Sig. (2- } \\
\text { tailed) }\end{array}$} \\
\hline \multirow[t]{2}{*}{ Mean } & \multirow[t]{2}{*}{$\begin{array}{l}\text { Std. } \\
\text { Deviation }\end{array}$} & \multirow[t]{2}{*}{$\begin{array}{l}\text { Std. } \\
\text { Error } \\
\text { Mean }\end{array}$} & \multicolumn{2}{|c|}{$\begin{array}{l}95 \% \text { Confidence } \\
\text { Interval of the } \\
\text { Difference }\end{array}$} & & & \\
\hline & & & Lower & Upper & & & \\
\hline $\begin{array}{l}- \\
23,800\end{array}$ & 8,178 & 1,293 & $-26,415$ & $-21,185$ & $\begin{array}{l}- \\
18,406\end{array}$ & 39 &, 000 \\
\hline
\end{tabular}

Tabel 8. Hasil Peningkatan Hasil Belajar Setelah Perlakuan

\begin{tabular}{|l|r|r|r|r|}
\hline Kelompok & Posttest & Pretest & Selisih Post-Pre & \% Peningkatan \\
\hline Eksperimen & 74,43 & 50,63 & 23,8 & 47,01 \\
\hline Kontrol & 65,45 & 52,3 & 13,15 & 25,14 \\
\hline
\end{tabular}

\section{Uji Hipotesis}

\section{Pengujian Hipotesis Pertama}

Hipotesis pertama berbunyi: Terdapat perbedaan hasil belajar mahasiswa pada pembelajaran online antara kelas yang menggunakan bahan ajar video tutorial dengan kelas yang menggunakan bahan ajar modul.
Berdasarkan uji prasyarat diperoleh bahwa data berdistribusi normal dan data tidak homogen. Uji hipotesis menggunakan Independent Sample T-test. Kriteria keputusan : jika nilai Sig. (2-tailed) < 0,05 maka $\mathrm{H}_{\mathrm{a}}$ diterima.

Dari Tabel 6 didapatkan nilai Signifikansi (2-tailed) adalah 0,001 $<0,05$ artinya $\mathrm{H}_{0}$ ditolak 
dan $\mathrm{H}_{\mathrm{a}}$ diterima. Hasil ini menunjukkan interpretasi bahwa terdapat perbedaan hasil belajar yang signifikan antara kelas menggunakan bahan video tutorial dengan kelas yang menggunakan bahan ajar modul pada mata kuliah Pengenalan Teknologi Informasi di ITEKES Bali.

\section{Pengujian Hipotesis Kedua}

Hipotesis kedua berbunyi: Terdapat peningkatan hasil belajar mahasiswa akibat penggunaan bahan ajar video tutorial. Berdasarkan uji prasyarat diperoleh bahwa data berdistribusi normal dan tidak homogen. Uji hipotesis menggunakan Paired Sample T-test. Kriteria keputusan : jika nilai Sig. (2-tailed) < 0,05 maka $\mathrm{H}_{\mathrm{a}}$ diterima.

Hasil analisis berikutnya pada Tabel 7 , menunjukkan adanya peningkatan hasil belajar mahasiswa akibat penggunaan bahan ajar video tutorial. Hal tersebut terlihat dari nilai sig. adalah $0,001<0,05$.

Pada Tabel 8 di atas, dapat dilihat peningkatan hasil belajar dari pretest ke posttest untuk kelas eksprerimen sebesar 47,01\% dan kelompok kontrol sebesar 25,14\%. Hal ini menunjukkan bahwa peningkatan hasil belajar kelas yang menggunakan bahan ajar video tutorial lebih tinggi dibandingkan kelas yang menggunakan bahan ajar modul.

\section{Pembahasan}

Penggunaan bahan ajar untuk kelas eksperimen adalah video tutorial. Bahan ajar ini berpotensi membuat mahasiswa bergairah untuk belajar. Materi pembelajaran mata kuliah Pengenalan Teknologi informasi khususnya topik Analisis Data dengan Software SPSS ini sebagian besar berisi praktek melakukan sesuatu dalam hal ini tutorial penggunaan software, akan lebih baik jika diajarkan menggunakan video agar mahasiswa dapat melakukan pengamatan secara langsung langkah-langkah praktek yang dilakukan.
Dengan menonton video tutorial, mahasiswa dapat melihat demonstrasi langkahlangkah pengoperasian software SPSS untuk melakukan analisis data. Bahan ajar video memiliki unsur suara dan gambar bergerak sehingga audio visual mahasiswa menjadi aktif. Hal ini tidak terjadi ketika mahasiswa belajar dengan bahan ajar modul yang hanya memiliki unsur tulisan dan gambar yang diam.

Hasil ini juga memberikan gambaran bahwa materi pembelajaran dapat meningkatkan pemahaman peserta didik jika disampaikan secara lebih jelas dan lebih mendekati nyata. Materi pembelajaran yang mudah dipahami tentu akan menghasilkan hasil belajar yang lebih baik. (Sukiyasa, 2013). Dengan demikian, bahan ajar video tutorial berkontribusi positif terhadap hasil belajar. Penggunaan video tutorial dalam proses pembelajaran memberikan kemudahan bagi mahasiswa dalam memahami materi pembelajaran. Mahasiswa dapat memahami materi pembelajaran lebih nyata terutama suatu materi yang mendemokan penggunaan software dalam hal ini software SPSS untuk melakukan analisis data.

Video dapat digunakan sebagai solusi untuk mengatasi rendahnya kemampuan peserta didik dalam memahami suatu konsep. Kelebihan penyajian video tutorial yang dapat diulang selama proses pembelajaran memudahkan peserta didik untuk memahami isi video (Sudiarta \& Sadra, 2016). Hal ini menunjukkan bahwa video merupakan media yang efektif digunakan untuk meningkatkan kemampuan mahasiswa untuk memahami suatu konsep.

Banyak hasil penelitian yang menyimpulkan bahwa penggunaan video dalam pembelajaran dapat meningkatkan motivasi peserta didik (Choi \& Johnson, 2005) dan memiliki kontribusi positif terhadap hasil belajar (Sarnoko dkk., 2016). Hasil penelitian Supryadi dkk. (2013) menunjukkan bahwa proses pembelajaran dengan menggunakan bahan ajar video memberikan suasana yang tidak membosankan dan menyenangkan bagi peserta 
didik agar perhatian peserta didik terfokus. Video dapat meningkatkan pemahaman peserta didik yang memiliki karakteristik belajar yang berbeda-beda, mulai dari audio, visual, dan audio-visual. Peningkatan pemahaman peserta didik akan berdampak pada peningkatan hasil belajar, sehingga dapat dikatakan bahwa penggunaan video dinilai efektif diterapkan dalam proses pembelajaran (Pambudi dkk., 2019).

Penelitian menujukkan bahwa penggunaan bahan ajar video tutorial dalam penyampaian materi Analisis Data dengan SPSS lebih tinggi dari pada pembelajaran yang menggunakan bahan ajar modul. Oleh karena itu,bahan ajar berupa video dapat digunakan dalam menyampaikan materi yang berisi tutorial melakukan sesuatu untuk meningkatkan hasil belajar.

\section{PENUTUP}

\section{Simpulan}

Berdasarkan hasil pengujian hipotesis diperoleh simpulan bahwa terdapat perbedaan hasil belajar kelas yang pembelajarannya menggunakan bahan ajar video tutorial dibandingkan dengan bahan ajar modul.Rerata hasil belajar kelas yang menggunakan bahan ajar video tutorial lebih tinggi dibandingkan kelas yang menggunakan bahan ajar modul. Hasil lainnya juga menunjukkan terdapat peningkatan hasil belajar mahasiswa akibat penggunaan bahan ajar video tutorial. Dapat disimpulkan bahwa video tutorial efektif digunakan dalam pembelajaran untuk meningkatkan hasil belajar.

\section{Saran}

Untuk meningkatkan hasil belajar mahasiswa khususnya di masa pandemi dimana pembelajaran dilaksanakan secara daring, diperlukan media yang tepat dan efektif. Para pengajar diharapkan menggunakan variasi penggunaan bahan ajar untuk meningkatkan hasil belajar mahasiswa salah satunya adalah penggunaan bahan ajar video. Disarankan kepada peneliti lainnya yang berminat untuk mengadakan penelitian lanjutan dengan membuat bahan ajar video dengan materi pembelajaran yang berbeda atau lebih luas lagi.

\section{Ucapan Terima Kasih}

Penelitian ini didanai oleh Direktorat Riset dan Pengabdian Masyarakat, Deputi Bidang Penguatan Riset dan Pengembangan, Kementerian Riset, Teknologi / Badan Riset dan Inovasi Nasional Republik Indonesia melalui program hibah Penelitian Dosen Pemula (PDP).

\section{DAFTAR PUSTAKA}

Ahmadi, F., Sutaryono, S., Witanto, Y., \& Ratnaningrum, I. (2017). Pengembangan media edukasi "Multimedia Indonesian Culture" (MIC) sebagai penguatan pendidikan karakter siswa Sekolah Dasar. Jurnal Penelitian Pendidikan, 34(2), 127136.

Alami, Y. (2020). Media Pembelajaran Daring pada Masa Covid-19. Tarbiyatu wa Ta'lim: Jurnal Pendidikan Agama Islam, 2(1), 4956

Atsani, K. L. G. M. Z. (2020). Transformasi media pembelajaran pada masa Pandemi COVID-19. Al-Hikmah: Jurnal Studi Islam, 1(1), 82-93.

Choi, H. J., \& Johnson, S. D. (2005). The effect of context-based video instruction on learning and motivation in online courses. The American Journal of Distance Education, 19(4), 215-227.

Creswell, J. W. (2012). Educational research. Boston: Pearson Education Inc.Dabbagh, N. \& Ritland, B. (2005). Online learning concepts, strategies, and application. New Jersey: Pearson

Firman, F., \& Rahayu, S. (2020). Pembelajaran online di tengah pandemi covid-19. Indonesian Journal of Educational Science (IJES), 2(2), 81-89.

Hadi, S. (2017, May). Efektivitas penggunaan video sebagai media pembelajaran untuk siswa sekolah dasar. In Seminar Nasional Teknologi Pembelajaran Dan Pendidikan Dasar 2017 (pp. 96-102) 
Kuntarto, E. (2017). Keefektifan Model Pembelajaran Daring Dalam Perkuliahan Bahasa Indonesia Di Perguruan Tinggi. Indonesian Language Education and Literature, 3(1), 99-110.

Moore, J. L., Dickson-Deane, C., \& Galyen, K. (2011). e-Learning, online learning, and distance learning environments: Are they the same?. The Internet and higher education, 14(2), 129-135.

Pambudi, S., Surjono, H. D., Sukardiyono, T., \& Hidayatulloh, I. (2019, November). VideoBased Blended Course for Computer Network Learning. In Journal of Physics: Conference Series (Vol. 1413, No. 1, p. 012025). IOP Publishing.

Rudiawan, D. (2015). Pengaruh Multimedia Model Tutorial Terhadap Hasil Belajar Gambar 3 Dimensi Siswa SMK. Jurnal Pendidikan.

Sarnoko, S., Ruminiati, R., \& Setyosari, P. (2016). Penerapan pendekatan SAVI berbantuan video pembelajaran untuk meningkatkan aktivitas dan hasil belajar IPS siswa kelas IV SDN I Sanan Girimarto Wonogiri. Jurnal Pendidikan: Teori, Penelitian, dan Pengembangan, 1(7), 1235-1241.

Sudiarta, I. G. P., \& Sadra, I. W. (2016). Pengaruh model blended learning berbantuan video animasi terhadap kemampuan pemecahan masalah dan pemahaman konsep siswa. Jurnal Pendidikan dan pengajaran, 49(2), 48-58.

Sukardi. (2003). Metodologi Peneltian Pendidikan: Kompetensi Dan Praktiknya. Jakarta: Bumi Aksara

Sukiyasa, K., \& Sukoco, S. (2013). Pengaruh media animasi terhadap hasil belajar dan motivasi belajar siswa materi sistem kelistrikan otomotif. Jurnal Pendidikan Vokasi, 3(1).

Supryadi, P. E., Jampel, I. N., \& Riastini, P. N. (2013). Penerapan media video pembelajaran sebagai aplikasi pendekatan contekstual teaching learning untuk meningkatkan hasil belajar IPA siswa kelas V. MIMBAR PGSD Undiksha, 1(1). Susmiati, E. (2020). Meningkatkan Motivasi Belajar Bahasa Indonesia Melalui Penerapan Model Discovery Learning dan
Media Video Dalam Kondisi Pandemi Covid-19 bagi Siswa SMPN 2 Gangga. Jurnal Paedagogy, 7(3), 210-215

Zhou, G., Chen, S., \& Chen, Z. (2020). Back to the spring of Wuhan: facts and hope of COVID19 outbreak. Frontiers of Medicine, 1-4. https://doi.org/10.1007/s11684-020-07589 